\title{
THE NUTRITIONAL STATUS OF ZOOPLANKTON IN A TROPICAL RESERVOIR: EFFECTS OF FOOD QUALITY AND COMMUNITY STRUCTURE
}

\author{
PINTO-COELHO, R. M., ${ }^{1}$ GIANI, A., ${ }^{2}$ MORAIS-JR., C. A., ${ }^{1}$ \\ CARVALHO-JR., E. R. ${ }^{1}$ and BEZERRA-NETO, J. F. ${ }^{3}$ \\ ${ }^{1}$ Laboratório de Gestão de Reservatórios Tropicais, Departamento de Biologia Geral, Instituto de Ciências Biológicas, \\ Universidade Federal de Minas Gerais, Belo Horizonte, Minas Gerais, Brazil \\ ${ }^{2}$ Laboratório de Ficologia, Departamento de Botânica, Instituto de Ciências Biológicas, \\ Universidade Federal de Minas Gerais, Belo Horizonte, Minas Gerais, Brazil \\ ${ }^{3}$ Programa de Pós-graduação em Ecologia, Conservação e Manejo da Vida Silvestre, Instituto de Ciências Biológicas, \\ Universidade Federal de Minas Gerais, Belo Horizonte, Minas Gerais, Brazil \\ Correspondence to: Ricardo Motta Pinto-Coelho, Laboratório de Gestão de Reservatórios Tropicais, Departamento de \\ Biologia Geral, ICB, UFMG, C.P. 486, CEP 31270-901, Belo Horizonte, Minas Gerais, Brazil, \\ e-mail: rmpc@icb.ufmg.br \\ Received October 7, 2002 - Accepted February 3, 2004 - Distributed May 31, 2005
}

(With 5 figures)

\begin{abstract}
The temporal variability of energetic reserves of zooplankton in the eutrophic Pampulha reservoir was investigated during two successive annual cycles. The effects of dominance of large filter-feeding cladocerans (Daphnia) and the occurrence of massive blooms of the cyanobacteria Microcystis on the energetic reserves of zooplankton were tested. This study showed that phytoplankton composition has a greater effect on energetic reserves of zooplankton. Some associations between lipid levels and the specific composition of zooplankton were also found. This study also demonstrated that the elementary composition of phosphorus in zooplankton can be used as an estimator of the nutritional status of zooplankton.
\end{abstract}

Key words: phosphorus, lipid, tropical zooplankton, nutritional status, reservoir.

\section{RESUMO}

\section{O status nutritivo do zooplâncton em um reservatório tropical:} efeitos da qualidade e da estrutura da comunidade

A variabilidade temporal de reservas energéticas do zooplâncton no reservatório eutrófico da Pampulha foi investigada durante dois ciclos anuais sucessivos. Foram testados os efeitos da presença dos grandes cladóceros (Daphnia) e a ocorrência de florações maciças da cianobactéria Microcystis sobre as reservas energéticas do zooplâncton. Este estudo mostrou evidências de que a composição do fitoplâncton apresentou efeito intenso sobre as reservas energéticas do zooplâncton. Foram também encontradas associações entre o nível de lipídeos e a composição específica do zooplâncton. Demonstrou-se ainda que a composição elementar do fósforo no zooplâncton pode ser usada como indicador do status nutricional do zooplâncton.

Palavras-chave: fósforo, lipídeo, zooplâncton tropical, status nutricional, reservatório. 


\section{INTRODUCTION}

Two of the most striking differences between tropical and temperate freshwater zooplankton are the smaller size of zooplankton and the relative scarcity of large filter-feeding Daphnia species in the tropics (Fernando et al., 1987). The most common hypotheses explaining these differences include the higher fish predation rates in the tropics (Northcote et al., 1990; Starling \& Rocha, 1990), the lower food quality or the toxicity of cyanobacteria commonly dominant in tropical waters (Porter \& Orcutt, 1980; Lampert, 1981), and the energetic constraints of living in warmer waters (Geller, 1986). Some factors associated with biogeography have also been mentioned (Matsumura-Tundisi, 1984).

The higher metabolic rates of zooplankton from the warmer tropical regions limit their energetic storage patterns. The allocation of energetic reserves can be assessed by measuring the total lipids since these compounds make up the bulk of energy reserves of zooplankton (Goulden \& Henry, 1984). The most important groups of crustacean zooplankton are known to accumulate significant amounts of lipids, mostly in the form of tryacylglicerols (Farkas, 1970). Nonetheless, the lipid content of zooplankton can suffer extensive temporal variations (Vanderploeg et al., 1992). Indeed, some recent investigations have demonstrated that tropical freshwater zooplankton usually has lower lipid levels. Additionally, conspicuous diel variations in these energetic reserves have also been observed (Pinto-Coelho et al., 1997a, b; Santeiro \& PintoCoelho, 2000).

Phosphorus is frequently a limiting resource in freshwater systems (Schindler, 1977), particularly for freshwater zooplankton (Hessen, 1992; Brett et al., 2000). Some empiric relationships between total phosphorus availability and zooplankton biomass have been found (Hanson \& Peters, 1984). Furthermore, some cladocerans, specially the daphnids, are known to accumulate higher amounts of phosphorus (Hessen, 1990). In the last two decades, experimental and empirical evidence supporting the theory of elemental homeostasis (C, $\mathrm{N}$, and $\mathrm{P}$ ) in zooplankton have been published (Sterner et al., 1992). This theory is mostly based on the fact that the variation of elemental composition $(\mathrm{C}, \mathrm{N}$, and $\mathrm{P}$ ) found in zooplankton biomass is lower than the variation observed in phytoplankton or seston particles (Hochstädter, 2000). This pattern indicates the possible existence of homeostasis in the elemental composition of zooplankton. Despite all the accumulated evidence, one possible drawback of a stoichiometric approach is that it ignores the biochemical characteristics of both substrate and consumers (Tang \& Dam, 1996), which renders the role of element composition as an indicator of nutritional status of zooplankton still unclear. Therefore, the search must go on for possible relationships between elemental composition of potential limiting elements and nutritional status of zooplankton.

The present study focused on a small tropical reservoir, the Pampulha reservoir in Brazil, that for the past decade has suffered increasing trophy. The main objective was to evaluate the modifications in community structure of zooplankton that was observed during two successive seasons. These modifications were induced by increase in trophy grade of the system and predation by planktivores. The study period initially covered a season during which zooplankton was dominated by large-bodied Daphnia pulses. In the second phase, the system was dominated by small cyclopoids as a response to increased predation pressure by fish. In both periods, extensive blooms of the cyanobacteria Microcystis were recorded. These circumstances allowed testing two hypotheses that could explain why tropical zooplankton tends to have a lower nutritional status. First, the possible effect of cyanobacteria on food quality and energy reserves of zooplankton was investigated. Furthermore, we looked for some empirical relationship between the dominance of Daphnia in the zooplankton and the lipid level of total zooplankton. The suitability of elementary composition of phosphorus for estimating the nutritional status of zooplankton was also investigated.

\section{MATERIAL AND METHODS}

\section{Study area}

Pampulha reservoir, with a $11 \times 10^{6} \mathrm{~m}^{3}$ volume and surface area of $2.1 \mathrm{~km}^{2}$, is located in the northern part of Belo Horizonte, the capital of Minas Gerais State. The reservoir was built in 1938 for supplying water, but in the early eighties the use of the reservoir for drinking water was interrupted due to the incidence of cyanobacteria blooms in the lake. Since then, the reservoir has 
exhibited several signs of eutrophication, including outbreaks of the macrophyte Eichhornia crassipes (1992-1995) and successive blooms of Microcystis aeruginosa (1980, 1988-1990, 1995-1997). In recent years, a sharp increase in the population of an exotic fish, the African cichlid tilapia (Oreochromis niloticus), also occurred in the reservoir (1997-1998).

\section{Sampling and laboratory procedures}

Algae, zooplankton, and samples for chemical analysis were collected at a central station $(\mathrm{z}=8$ $\mathrm{m}$ ) in the reservoir in a location used for regular monitoring for more than 15 years. Samplings were done monthly between 1993 and 1995, and every two weeks from 1996 to 1998. Phytoplankton and samples for chemical analysis were collected with a Van Dorn bottle at the following depths: $0 \mathrm{~m}, 0.5$ $\mathrm{m}, 1.0 \mathrm{~m}, 2.0 \mathrm{~m}, 4.0,6.0 \mathrm{~m}$, and $0.5 \mathrm{~m}$ from the bottom. Zooplankton was collected using a $5.1 \mathrm{~L}$ Schindler-Patalas trap equipped with a $90 \mu \mathrm{m}$ mesh net. Different depths covering the water column were considered: $0,2,4$, and $6 \mathrm{~m}$, but in this paper only zooplankton data from $2.0 \mathrm{~m}$ were used. Water transparency and conductivity were measured in situ by means of a Secchi disk $35 \mathrm{~cm}$ in diameter and a Yellow Springs device, respectively.

Water samples for chemical analysis were deep frozen $\left(-25^{\circ} \mathrm{C}\right)$. The determination of inorganic nitrogen (ammonium) was done according to Mackereth et al. (1978). Total phosphorus was determined according to Murphy \& Riley (1962). Chlorophyll-a was determined using the conventional technique proposed by Lorenzen (1967); POC was estimated using a procedure described in Torres et al. (1998).

Phytoplankton samples fixed with lugol acetic were routinely enumerated using the Utermöhl (1958) technique. Species identification was carried out following the descriptions provided by Eterovick \& Giani (1997). At least 400 individuals of the dominant species were counted in each sample. The biovolume was estimated using the equations from Root (1981).

Zooplankton was fixed using a buffered formalin solution saturated with sucrose. A minimum of 700 individuals were enumerated and measured in each sample. A M3C-Leica dissecting stereomicroscope was used. In the early period (1993-1996), all individuals were measured by means of a calibrated eyepiece. Biomass estimation was done using allometric equations relating length to dry weight as derived by McCauley et al. (1989) and Masundire (1994).

Another $250 \mathrm{ml}$ zooplankton sample was taken for chemical and biochemical analysis. The sample was placed in a thermos box filled with ice, and within 30 minutes transported to the laboratory. There the organisms were filtered on $160 \mu \mathrm{m}$ inox gauze that was carefully transferred to a $10 \mathrm{~cm}$ Nalgene petri dish, wrapped in aluminum foil, $\mathrm{N}_{2}$ saturated, and placed in a dissecator air-tightened with silica gel. The dissecator was stored in a conventional freezer $\left(-25^{\circ} \mathrm{C}\right)$. Next day, the frozen samples were placed in an Edwards L5KR lyophilizer for $24 \mathrm{hs}$. After freeze-drying, the zooplankton samples were stored again, using the same procedure until the date of chemical analysis.

\section{P-content of zooplankton}

A $3.00 \mathrm{mg}$ (weighed using a high precision Mettler balance) aliquot of freeze-dried zooplankton was placed in $50 \mathrm{ml}$ glass tube, following which $0.1 \mathrm{ml}$ of distilled water was added to each tube. The sample was mechanically grounded. The homogenate was then transferred to $125 \mathrm{ml}$ Pyrex flasks for chemical digestion with potassium persulfate. The samples were allowed to evaporate until about $0.5-1.0 \mathrm{ml}$ remained. The extract was ressuspended to exactly $50 \mathrm{ml}$ using distilled water, and the phosphorus content was colorimetrically determined using the molybdate-ascorbic acid solution prepared according to Murphy \& Riley (1962). A Shimadzu UV-VIS spectrophometer equipped with $5.0 \mathrm{~cm}$ quartz cuvettes was used.

\section{Analysis of lipids}

Total lipids were measured using a colorimetric method (Zollner \& Kisrch, 1962) modified by Meyer \& Walther (1988). A 0.50 to $2.00 \mathrm{mg}$ aliquot of freeze-dried zooplankton was mechanically grounded after adding $0.1 \mathrm{ml}$ of distilled water. After chemical digestion (with $\mathrm{NaOH}, 80^{\circ} \mathrm{C}, 2 \mathrm{hs}$ ), $1.0 \mathrm{ml}$ of a solution of fosforic acid and vaniline was added for color development. After exactly 30 minutes, sample absorbance was measured on a Shimadzu UV-VIS spectrophotomer $(\lambda=546 \mathrm{~nm})$ using a $1.0 \mathrm{~cm}$ glass cuvette. The standard solution was made of cholesterol (SIGMA, $99.99 \%)$. 


\section{RESULTS}

During the past decade, Pampulha reservoir has suffered a steady increase in eutrophication, as shown by the long-term evolution of water transparency, electric conductivity, total phosphorus, and ammonium (Fig. 1). The Secchi disk readings showed a clear decrease in the 1995-1998 period with annual means of $83,78,47$, and $46 \mathrm{~cm}$, respectively. Conductivity and nutrients showed a evident seasonal pattern with higher values during the dry season, especially during the months of August, September, and October. Despite this seasonal pattern, there were clear increases in the annual maxima of all these variables during the study period. The annual maxima conductivity for the 1994-1998 periods were, respectively, 322, 340, 370,378 , and $401 \mu \mathrm{S} . \mathrm{cm}^{-1}$. Similar patterns were also found for inorganic nitrogen (ammonium) and total phosphorus. The annual maxima of total phosphorus (bottom values - $6 \mathrm{~m}$ ) for the 19931998 periods were, respectively, 47, 77, 158, 166, 205, and $269 \mu \mathrm{g}$ P-PO4.L ${ }^{-1}$ (Fig. 1).

During 1996 and 1997, an intensive survey of phytoplankton and zooplankton (sampling every two weeks) was performed. The data from this period are represented in Fig. 2. In 1996, the phytoplankton community was dominated by small chlorococcales (Oocystis lacustris, Scenedesmus acus, and Tetraedron minimum). In 1997, with the disappearance of Daphnia from the lake, the small phytophlagellates like the cryptophyceae Cryptomonas erosa, C. brasiliensis, and Rhodomonas sp. were also initially abundant. With the onset of more stable climatic conditions during the dry season (higher daily radiation and less windy), the structure of phytoplankton changed with the appearance of several pulses of cyanobacteria that bloomed in the lake, mostly between May and early December (Fig. 2A). The following species were regularly found: Microcystis aeruginosa, $M$. viridis, and $M$. flos-aquae.

In this two-year period, the reservoir's zooplankton community changed noticeably, and in 1996 it was dominated by the cladoceran Daphnia laevis, of which in that year there were at least three populational pulses (Fig. 2B). In 1997, this cladoceran disappeared from the lake and the small cyclopoid Thermocyclops decipiens became dominant, with numerous peaks in May, July, September, October, and December. Secondary pulses of the cladoceran Diaphanosoma birgei and Moina micrura were also observed in 1997 (Fig. 2B).

We routinely measured the nutritional status of zooplankton community during 1996 and 1997 (Fig. 3). The nutritional condition of zooplankton was evaluated using two approaches: the content of total lipids of zooplankton, and the elementary content of phosphorus. The lipid content of total zooplankton ranged between $4.12 \%$ and $32.12 \%$ of dry weight, with an average of $8.55 \pm 4.35 \%$ of dry weight for the 1996-1997 period (Fig. 3B: pooled 1996-1997 data). The elementary composition of phosphorus was also monitored biweekly (Fig. 3C). The P-content ranged between $0.39 \%$ and $2.35 \%$ P-DW, with an average of $1.28 \pm$ $0.44 \%$ P-DW (C:P molar $=113.4)$ for the pooled data (1996-1997). Figure 3 also demonstrates that both variables tended to show lower values during the periods of cyanobacteria blooms in the reservoir (vertical dashed lines).

The study found a significant linear correlation between the elementary content of phosphorus and the total lipid level in zooplankton community biomass. The linear regression between these two variables was significant $(\mathrm{F}=12.77, \mathrm{p}<0.001, \mathrm{df}=36)$. This suggests that the phosphorus content can also be regarded as a good estimator of zooplankton food reserves in Pampulha reservoir (Fig. 4).

We regrouped the measurements of lipids and P-content according to specific years and conditions in the lake, after which the effects of Daphnia dominance and cyanobacteria blooms on the nutritional status of zooplankton as expressed by lipids and P-content were examined (Table 1). The annual average of lipid content of total zooplankton was higher in the first year with averages of $9.11 \%$ and 7.96\% DW for 1996 and 1997, respectively. The total phosphorus content was also higher in 1996, with an annual average of $1.41 \%$ and $1.13 \%$ DW for 1997. Since there was a strong dominance of daphnids in 1996, these findings suggest that these organisms possibly have some impact on the overall nutritional condition of the zooplankton community.

There was a non-significant decrease of lipids in periods when $D$. laevis was absent from the zooplankton. The total lipids were $7.83 \pm$ SD $1.93 \%$ DW for periods without Daphnia and $8.02 \pm 2.02 \%$ DW, when Daphnia was present in the samples $(\mathrm{F}=$ 0.084, $\mathrm{p}<0.774, \mathrm{n}=38$ ) (Fig. 5). The dominance 
of this cladoceran in the zooplankton showed a stronger effect on the zooplankton P-content. This variable reached an average of $1.43 \pm 0.42 \%$. P-DW in the presence of this cladoceran, decreasing to $1.13 \pm 0.39 \%$ P-DW in the absence of daphnids from the reservoir $(\mathrm{F}=5.043, \mathrm{p}<0.031, \mathrm{n}=39)$ (Fig. 5).

The cyanobaceria Microcystis had a significant influence on both the total lipid and P-content of zooplankton. Zooplankton nutritional status as expressed by these two variables suffered significant reductions during algal blooms. Total lipids, for example, decreased from $8.41 \pm 1.89 \%$ DW to $6.75 \pm$ $1.36 \%$ DW $(\mathrm{F}=5.704, \mathrm{p}<0.023, \mathrm{n}=36)$ in the presence of high densities of Microcystis (> $5.0 \mathrm{x}$ $10^{6} \mu \mathrm{m}^{3} . \mathrm{mm}^{-3}$ ) (Fig. 5). The P-content also suffered a significant reduction during blooms, going from $1.35 \pm 0.42 \%$ P-DW to $1.08 \pm 0.26 \%$ P-DW (F = 4.998, $\mathrm{p}<0.032, \mathrm{n}=35$ ) (Fig. 5).

\section{DISCUSSION}

The modifications observed in zooplankton structure between 1996 and 1997 are possibly associated with increasing trophy fishing and fish predation. In 1996, during June, July, and September, respectively, at least three events of massive fish mortality occurred in the reservoir; in at least one of them, extensive death of zooplankton was also observed (Pinto-Coelho et al., 2003). These events are possibly associated with rapid climatic changes, the so-called cold fronts, characterized by abrupt changes in the air temperatures caused by the entrance of cold, oceanic air fronts from the subtropical areas of the Atlantic Ocean. These can last from 1 to 5 days, and often induce rapid circulation in water columns in shallow water bodies such as Pampulha reservoir. In highly eutrophic systems, column circulation often causes a sharp decrease or even total disappearance of dissolved oxygen from surface waters for short periods, usually during the night. In 1996, fish mortality in Pampulha occurred in periods of high cyanobacteria densities. Thus, the possible effects of cyanotoxins in these fish deaths cannot be ruled out. These species of cyanobacteria are known to produce toxins, known as microcystines (FerrãoFilho et al., 2000). Stressful conditions may have contributed to maintain the fish populations at lower levels in 1996. In the following year, despite the occurrence of algal blooms, no major event of fish mortality was observed in the lake. The juvenile fish recruitment possibly allowed rapid recovery of fish standing stocks, which maintained high predation rates upon zooplankton during 1997 and the following years. Increased vertebrate predation possibly induced changes in the structure of this community, such as the disappearance of large Daphnia laevis from the lake.

TABLE 1

Amplitudes and mean values of energetic content (total lipids) and elementary composition in phosphorus expressed as percentages of zooplankton dry weight in Pampulha reservoir.

\begin{tabular}{|c|c|c|c|c|c|c|c|c|c|c|}
\hline \multirow{2}{*}{ Year } & \multicolumn{5}{|c|}{ Lipid } & \multicolumn{5}{|c|}{ P-zoo } \\
\hline & Min & Med & Max & SD & $n$ & Min & Med & Max & SD & $n$ \\
\hline 1996 & 4.49 & 9.11 & 32.15 & 5.68 & 20 & 0.73 & 1.41 & 2.35 & 0.41 & 20 \\
\hline 1997 & 4.12 & 7.96 & 12.08 & 1.80 & 19 & 0.39 & 1.13 & 2.05 & 0.41 & 19 \\
\hline 1996-1997 & 4.12 & 8.55 & 32.15 & 4.33 & 39 & 0.39 & 1.28 & 2.35 & 0.44 & 39 \\
\hline \multicolumn{11}{|l|}{ Treatment } \\
\hline With Daphnia & 5.51 & 8.02 & 12.75 & 2.02 & 19 & 0.73 & 1,43 & 2.35 & 0.42 & 19 \\
\hline Without Daphnia & 4.12 & 7.83 & 12.08 & 1.93 & 19 & 0.39 & 1.13 & 2.05 & 0.39 & 20 \\
\hline Anova & \multicolumn{5}{|c|}{$F=0.084, p<0.774, n=38$} & \multicolumn{5}{|c|}{$F=5.043, p<0.031, n=39$} \\
\hline Blooms & 4.49 & 6.75 & 8.78 & 1.36 & 9 & 0.76 & 1.08 & 1.51 & 0.26 & 9 \\
\hline Without blooms & 5.54 & 8.41 & 12.75 & 1.89 & 27 & 0.65 & 1.35 & 2.35 & 0.42 & 26 \\
\hline Anova & \multicolumn{5}{|c|}{$F=5.704, p<0.023, n=36$} & \multicolumn{5}{|c|}{$F=4.998, p<0.032, n=35$} \\
\hline
\end{tabular}



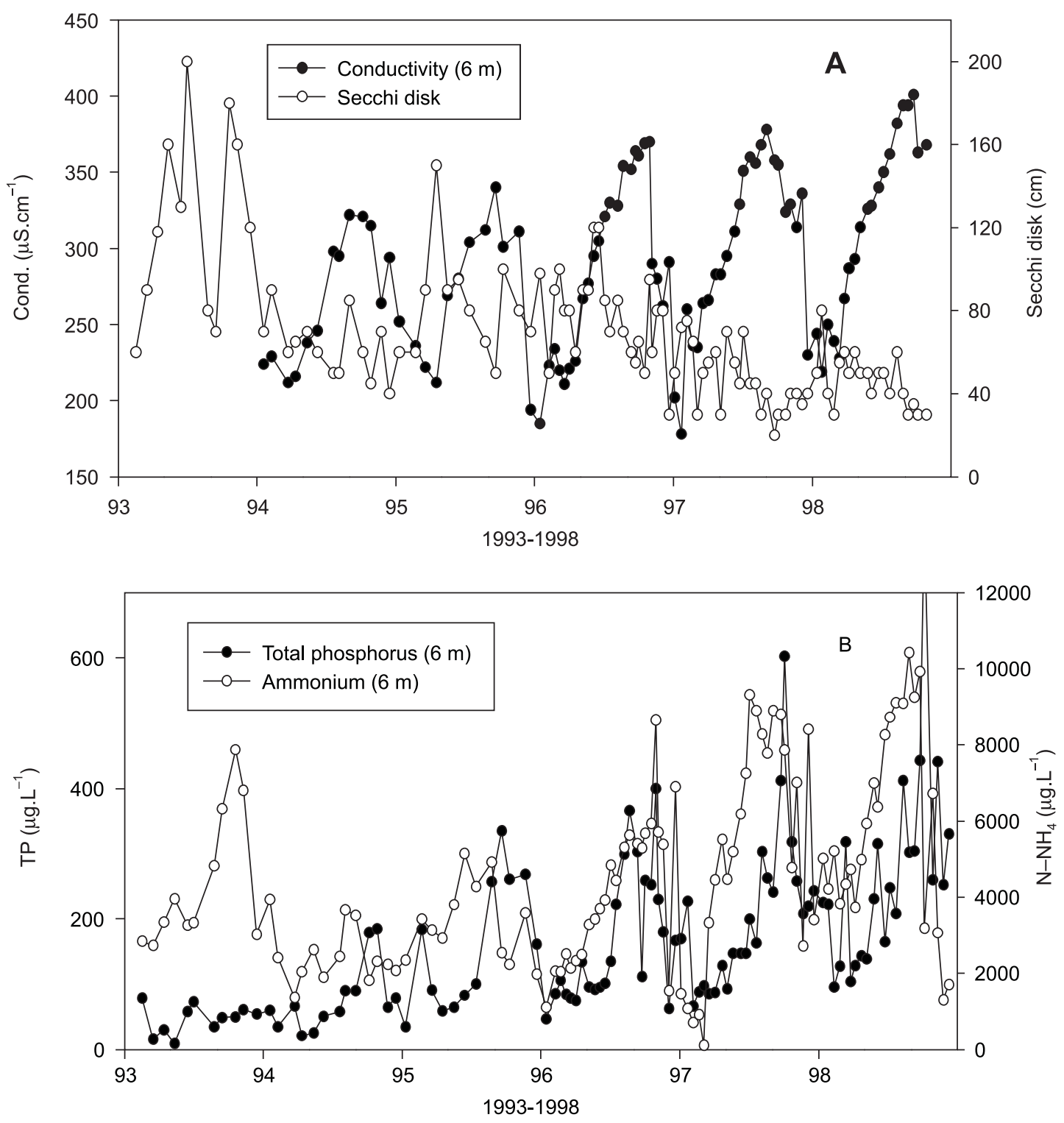

Fig. 1 - Temporal variation of (A) water transparency (Secchi Disk), electric conductivity (6 m), (B) total phosphorus (6 m), and ammonium $(6 \mathrm{~m})$ in Pampulha reservoir. $\mathrm{TP}=$ total phosphorus, $\mathrm{N}-\mathrm{NH}_{4}=$ ammonium, $\mathrm{COND}=$ electric conductivity, $\mathrm{Secchi}=$ water transparency.

Plankton community monitoring in Pampulha reservoir in the three subsequent years (1998-2000) demonstrated that the zooplankton community continued to be dominated by Thermocyclops, and that daphnids were absent throughout these years (Pinto-Coelho et al., 2001). An inventory of fish fauna (Godinho et al., 1992) showing 944 specimens in different regions of the reservoir demonstrated that tilapia (Oreochromis niloticus) were already the dominant organisms, with $82.4 \%$ of the total catch. Other species such as the piscivorous traíra (Hoplias lacerdae, H. malabaricus) and a small piranha, Serrasalmus were also common. However, after 1997 the population of this exotic African fish became 
largely dominant in the reservoir. In 1999, another inventory of the fish fauna was made. About 1200 specimens were collected, weighed, and identified. The local fish fauna was poor in species and strongly dominated by only one species of an African tilapia,
Oreochromis niloticus, a common inhabitant of most Brazilian reservoirs (Álvares et al., 2000). The increase of the tilapia population in the reservoir may explain the disappearance of Daphnia and the increase of small cyclopoids in the lake.

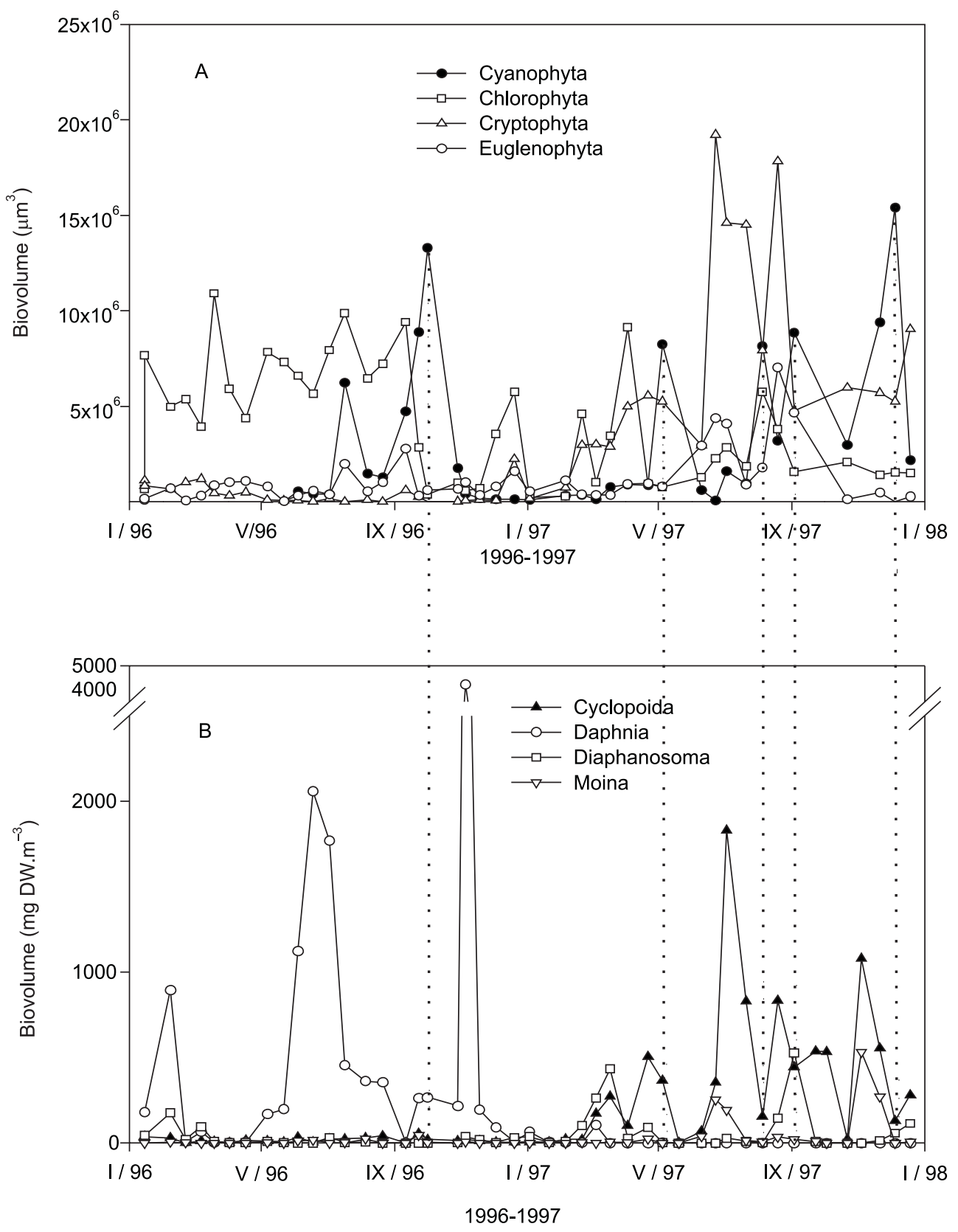

Fig. 2 - Seasonal variation of phytoplankton biovolume (A) and biomass in dry weight of major zooplankton groups (B) in Pampulha reservoir, Minas Gerais, Brazil. Vertical lines correspond to bloom periods defined as the density of cyanobacteria $>5.0 \times 10^{6} \mu \mathrm{m}^{3}$. 

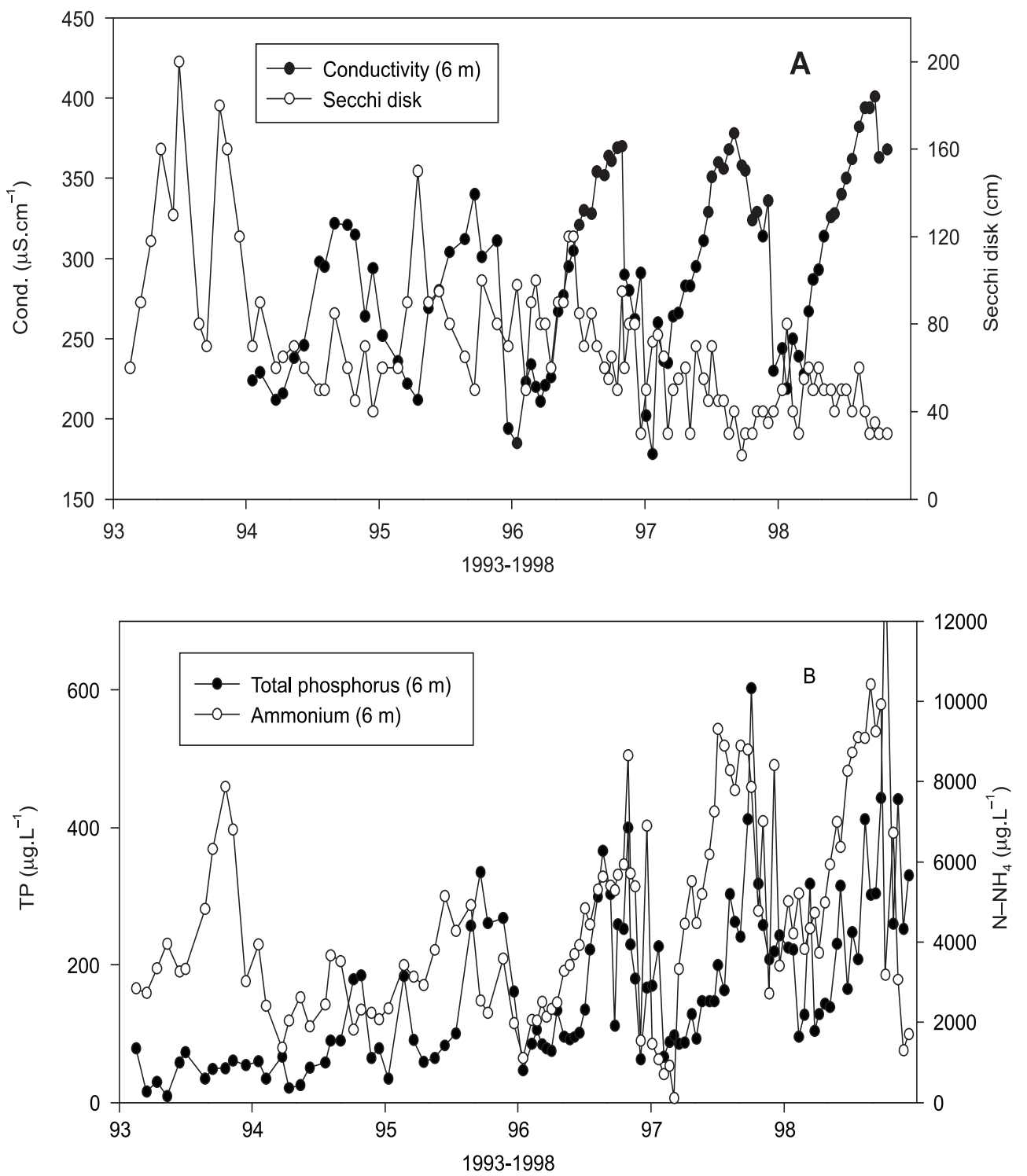

Fig. 3 - Cyanobacteria, total lipids, and P-content of zooplankton in Pampulha reservoir, Minas Gerais, Brazil. Vertical lines correspond to bloom periods defined as the density of cyanobacteria $>5.0 \times 10^{6} \mu \mathrm{m}^{3}$.

The changes in the zooplankton community had no significant effect on the patterns of lipid accumulation. However, they were associated with the zooplankton P-content. Despite large variations in the total zooplankton biomass, no significant difference was found in the profile of lipid reserves in periods with and without Daphnia. In contrast, the amount of total lipids of zooplankton as well as the elementary composition of phosphorus experienced significant reductions during periods of cyanobacteria blooms. 


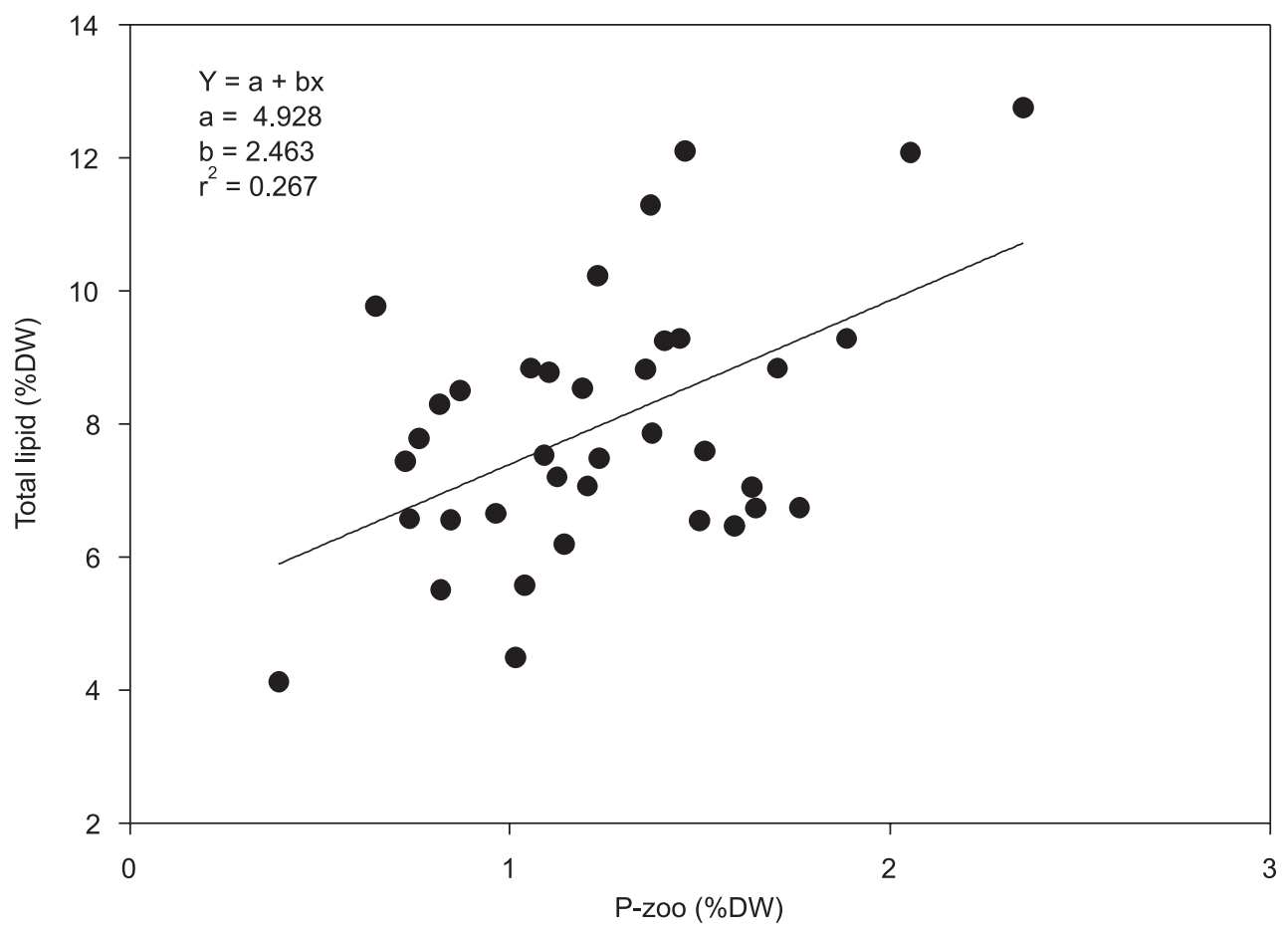

Fig. 4 - Linear regression model between the elemental content of phosphorus (P-zoo) and the total lipids of zooplankton.

Cyanobacteria are known as organisms of poor food quality with respect to zooplankton (Reinikainen et al., 1995) but tropical zooplankton, particularly daphnids, are often forced to ingest these items in their normal diet (EskinaziSant'Anna et al., 2002). Several studies have shown a reduction in the growth and reproduction of Daphnia either due to the higher rate of food rejection in the presence of filamentous cyanobacteria or to its poor nutritional quality, or to the presence of cyanotoxins (Lampert, 1981; Gliwicz \& Lampert, 1990). But it is known that zooplankton species differ considerably in their responses to toxic cyanobacteria (DeMott et al., 1991). Differences were also found between clones of the same species (Hietala et al., 1997), suggesting a genotype-dependent response. Furthermore, it is also possible that during cyanobacteria blooms, more resistant zooplankton species are selected.

Stoichiometry, a familiar approach in studies about zooplankton production, typically places food resources into three major elemental categories: carbon, nitrogen, and phosphorus (Tang \& Dam, 1996). Several studies have concluded that freshwater zooplankton is usually P-limited (e.g. Hessen, 1992). For purposes of comparison, we did an approximate estimation of molar C:P ratios for the Pampulha zooplankton using a constant proportion of $49 \%$ (Berberovic, 1990) of carbon and varying $\mathrm{P}$-values, as presented in Fig. 3. The annual averages were 112.6 and 153.3 for 1996 and 1997, respectively. The P-content of zooplankton found in this study and the estimated molar C:P ratios above confirmed that this community had lower phosphorus levels than most temperate zooplankton (Hessen, 1990; Hessen \& Lyche, 1991). In the lake Constance (Germany), for example, the molar $\mathrm{C}: \mathrm{P}$ ratios for zooplankton range usually between 45 and 65 (Hochstädter, 2000). Even considering the fact that these C:P ratios were not estimated at the species level, the higher values found in the present study can be seen as evidence of the limiting role of phosphorus for zooplankton in Pampulha reservoir. 

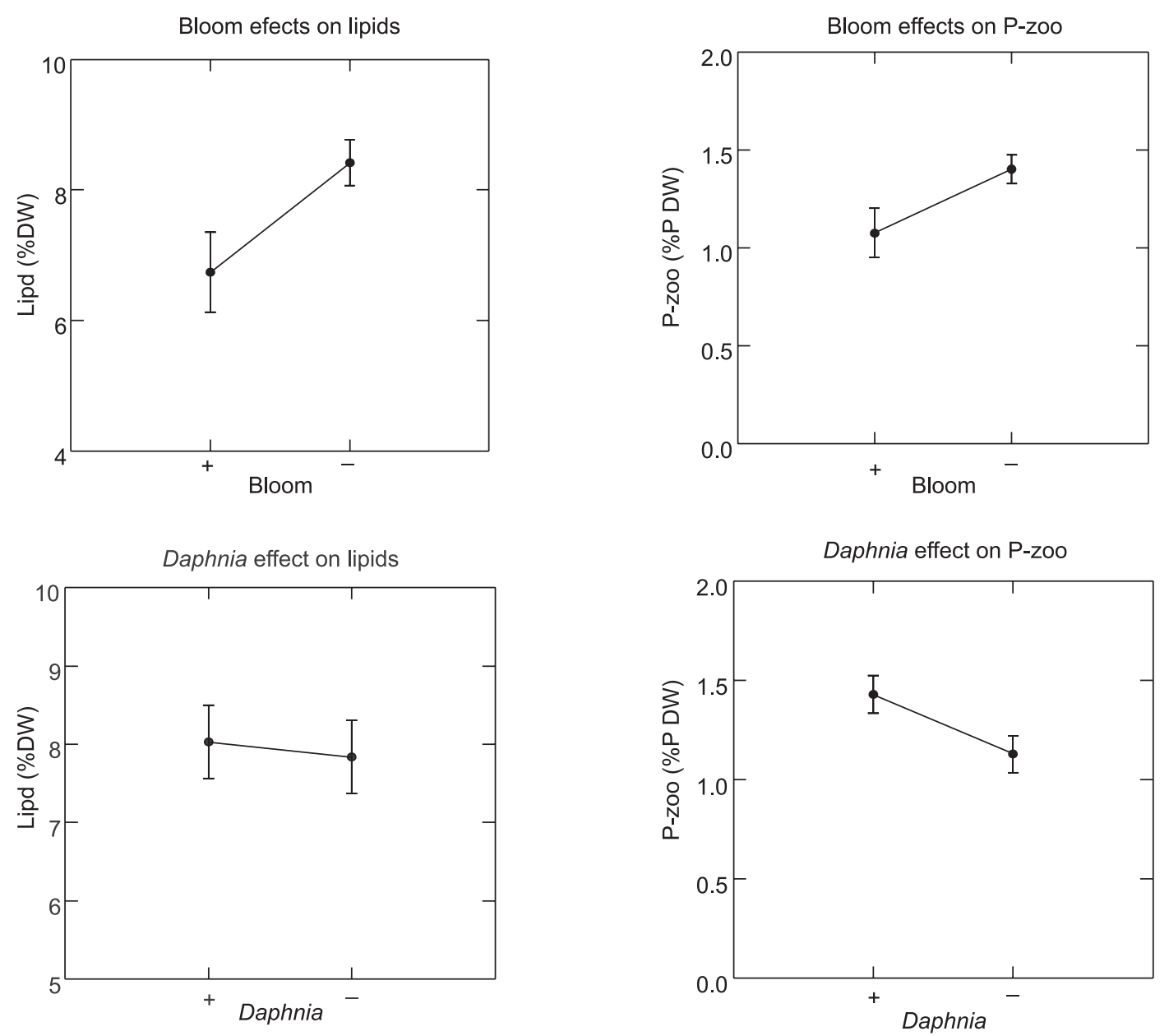

Fig. 5 - Mean and standard deviations of total lipid and P-content of zooplankton according to density of cyanobacteria (bloom defined as the biovolume $\left.>5.0 \times 10^{6} \mu \mathrm{m}^{3}\right)$ and Daphnia presence in the zooplankton (Daphnia biomass $\left.>10.0 \mathrm{mgDW} . \mathrm{m}^{-3}\right)$. Symbols: $(+)$ present; (-) absent.

One possible drawback of the stoichiometric approach is that it ignores biochemical constraints on both substrate and consumers. As Tang \& Dam (1996) admit, there is a need for more empirical research in order to confirm the robustness of predictions arrived at through stoichiometric models. The present study found a significant relationship between total lipids of zooplankton and the elemental content of phosphorus in the biomass. Lipids and carbohydrate are the main energetic compounds of these animals (Farkas, 1970). The relationship between a limiting nutrient (P) and one of main energetic compounds of zooplankton suggests the key role exerted by phosphorus in the energetic metabolism of zooplankton. The stoichiometry theory predicts that the element in excess will be differentially regenerated in order to maintain rigid elemental ratios in the biomass.

The correspondence between P-content and total lipids is not always consistent. The dominance of daphnids had no significant effect on lipid reserves, but these organisms were clearly associated with higher phosphorus levels in the total zooplankton biomass. Hessen (1990) has already found that this genus has the highest phosphorus amounts in freshwater zooplankton. Furthermore, the highest values for total lipids of tropical zooplankton were found in a community dominated by Diaphanosoma and not Daphnia (Pinto-Coelho 
et al., 1997b). Therefore, the structure of a zooplankton community may have a strong influence on the relationship between energetic reserves and elemental composition, making predictions arrived at through a stoichiometric approach much more difficult. Additionally, recent experimental evidence shows that the P-content of zooplankton is linked with excretory metabolism, which is affected by shortterm variations and food supply (Macedo \& Pinto-Coelho, 2000).

This study confirms our previous findings suggesting that tropical zooplankton normally tend to have a lower profile of energetic reserves as measured by total lipids. The amount of total lipids in different tropical reservoirs is usually lower than 15\% (Pinto-Coelho et al., 1997a). In most cases, a conspicuous diel cycle with higher values was found during the night (Pinto-Coelho et al., 1997a; Santeiro \& Pinto-Coelho, 2000). These patterns are possibly a result of the higher energetic demand of organisms living in temperatures that are always higher than $18^{\circ} \mathrm{C}$. In optimal conditions of food supply, total lipids of tropical zooplankton can reach values as high as $25 \% \mathrm{DW}$, as was observed for short periods in a zooplankton community dominated by Diaphanosoma birgei in fertilized plankton ponds of hatchery stations (Pinto-Coelho et al., 1997b). Similar values were also obtained in laboratory cultures of Daphnia laevis or Moina micrura that fed at $20^{\circ} \mathrm{C}$ on the green algae Ankistrodesmus gracilis (Macedo, 1999). These optimal conditions of food supply, however, are rarely found in the open waters of tropical lakes and reservoirs.

\section{CONCLUSIONS}

This study provided data on the effect of food quality in the energetic reserves and P-content of zooplankton in a tropical reservoir. The food quality effect on energetic reserves is present even considering extensive modifications in zooplankton structure. However, unlike total lipids, the P-content of zooplankton was also affected by the changes in the taxonomic structure of zooplankton, suggesting that community structure may have an important role in the internal cycling of a limiting element (phosphorus) in Pampulha reservoir. The study also showed a significant linear relation between the total lipid and the elemental composition of phosphorus in zooplankton.

Acknowledgements - We wish to thank the city of Belo Horizonte for supporting this research (grant 3998, FUNDEP/SMMA/PBH); the Fundação de Amparo à Pesquisa do Estado de Minas Gerais (FAPEMIG)g for a grant to Elildo R. Carvalho Jr., and the National Research Council (CNPq) for a research grant to Ricardo M. PintoCoelho. We also thank an anonymous referee for comments and suggestions on an earlier version of the manuscript.

\section{REFERENCES}

ÁLVARES, E., CANELAS, M., COSTA, R., DIAS, L., RIBEIROMENDES, H. \& PINTO-COELHO, R. M., 2000, Aspectos socioeconômicos e estimativa da atividade de pesca no reservatório da Pampulha, Belo Horizonte, MG. Anais V Simpósio de Ecossistemas Brasileiros, Vitória, Brasil, pp. 375-382.

BEBEROVIC, R., 1990, Elemental composition of two coexisting Daphnia species during the seasonal course of population development in lake Constance. Oecologia, 84: 340-350.

BRETT, M., MULLER-NAVARRA, D. C. \& PARK, S. K., 2000, Empirical analysis of the effect of phosphorus limitation on algal food quality for freshwater zooplankton. Limnol. Oceanogr., 45: 1564-1575.

DeMOTT, W. R., ZHANG, Q.-X. \& CARMICHAEL, W. W., 1991, Effects of toxic cyanobacteria and purified toxins on the survival and feeding of a copepod and three species of Daphnia. Limnol. Oceanogr., 36: 1346-1357.

ESKINAZI-SANT'ANNA, E. M., MAIA-BARBOSA, P. M. \& BARBOSA, F. A. R., 2002, On the natural diet of Daphnia laevis in the eutrophic Pampulha reservoir (Belo Horizonte, Minas Gerais). Braz. J. Biol., 62(3): 445-452.

ETEROVICK, P. C. \& GIANI, A., 1997, Levantamento taxonômico das Chlorophyta (Volvocales, Chlorococcales, Zygnematales) do Reservatório da Pampulha, MG. Rev. Brasil. Bot., 20: 7990.

FARKAS, T., 1970, Fats in fresh water crustaceans. Acta Biol. Acad. Sci. Hung., 21: 225-233.

FERNANDO, C. H., PAGGI, J. C. \& RAJAPASKA, R., 1987, Daphnia in tropical lowlands. Mem. Inst. Ital. Idrobiologia, 45: 107-141.

FERRÃO-FILHO, A., AZEVEDO, S. M. F. O. \& DEMOTT, W., 2000, Effects of toxic and non-toxic cyanobacteria on the life history of tropical and temperate cladocerans. Freshwat. Biol., 45: 1-20.

GELLER, W., 1986, Diurnal vertical migration of zooplankton in a temperate great lake (L. Constance): A starvation avoidance mechanism? Arch. Hydrobiol., 74 (supplement): 1-60.

GLIWICZ, Z. M. \& LAMPERT, W., 1990, Food thresholds in Daphnia species in the absence and presence of blue-green filaments. Ecology, 71: 691-702.

Godinho, H., SANTOS, G. B., Alves, C. B. M. \& FORMAGIO, P., 1992, Os peixes e a pesca na represa da Pampulha, Belo Horizonte, MG. In: H. Godinho (ed.), Anais do seminário da bacia hidrográfica da Pampulha. Segrac, Belo Horizonte, 186p. 
GOULDEN, C. E. \& HENRY, L. L., 1984, Lipid energy reserves and their role in cladocera. In: D. G. Meyers \& J. R. Strickler (eds.), Trophic interactions within aquatic ecosystems. Selected Symposium AAAS, Washington, D.C., 685p.

HANSON, J. \& PETERS, R. H., 1984, Empirical prediction of crustacean zooplankton biomass and profundal macrobenthos biomass in lakes. Can. J. Fish. Aquat. Sci., 41: 439-445.

HESSEN, D. O., 1990, Carbon, nitrogen and phosphorus status in Daphnia at varying food conditions. J. Plankton Res., 12: 1239-1249.

HESSEN, D. O., 1992, Nutrient element limitation of zooplankton production. Am. Nat., 140: 799-814.

HESSEN, D. O. \& LYCHE, A., 1991, Inter- and intraspecific variations in zooplankton element composition. Arch. fur Hydrobiol., 121: 343-353.

HIETALA, J., LAURÉN-MÄÄTTÄ, C. \& WALLS, M., 1997, Life history responses of Daphnia clones to toxic Microcystis at different foods levels. J. Plankton Res., 19: 917-926.

HOCHSTÄDTER, S., 2000, Seasonal changes in C:P ratios of seston, bacteria, phytoplankton and zooplankton in a deep mesotrophic lake. Freshwat. Biol., 44: 453-464.

LAMPERT, W., 1981, Inhibitory and toxic effects of blue green algae on Daphnia. Int. Revue ges. Hydrobiol., 66: 285-298.

LORENZEN, C. J., 1967, Determination of chlorophyll and phaeopigments: spectrophotometric equations. Limnol. Oceanogr., 12: 343-346.

MACEDO, C. F., 1999, O efeito das algas Scnedesmus quadricauda e Ankistrodesmus gracilis no desenvolvimento ontogenético e no status nutricional de Daphnia laevis e Moina micrura. Dissertação de Mestrado, Universidade Federa de Minas Gerais, 160p

MACEDO, C. F. \& PINTO-COELHO, R. M., 2000, Diel variations in respiration, excretion rates and nutritional status of zooplankton from the Pampulha reservoir, Belo Horizonte, MG. J. Exp. Zool., 286: 671-682.

MACKERETH, F. J. H., HERON, J. \& TALLING, J. F., 1978, Water analysis: some revised methods for limnologists. Freshwater Biology Association. Scientific Publication 36, Cumbria, UK, 120p.

MASUNDIRE, H. M., 1994, Mean individual dry weight and length weight regressions of some zooplankton of lake Kariba. Hydrobiologia, 272: 231-238.

MATSUMURA-TUNDISI, T., 1984, Occurrence of species of the genus Daphnia in Brazil. Hydrobiologia, 112: 161-165.

MCCAULEY, D. F., LAWRENCE, S. G., MACIVER, M. A. \& FINDLAY, W. J., 1989, Range of variation in the estimates of dry weight for planktonic crustacea and rotifera from temperate North American lakes. Can. Tech. Rep. of Fish. Aquat. Sci., 1666: 1-49.

MEYER, E. \& WALTHER, A., 1988, Methods for the estimation of protein, lipid, carbohydrate and chitin levels in fresh water invertebrates. Arch. fur Hidrobiol., 113: 161-177.

MURPHY, J. \& RILEY, J. P., 1962, A modified single solution method for the determination of phosphate in natural waters. Anal. Chim. Acta, 27: 31-36.

NORTHCOTE, T. G., ARCIFA, M. S. \& MUNRO, K. A., 1990, An experimental study of the effects of fish zooplanktivory on the phytoplankton of a Brazilian reservoir. Hydrobiologia, 194: 31-45.
PINTO-COELHO, R. M., AMORIM, M. K. \& COSTA, A. R., 1997a, Temporal dynamics of lipids in the zooplankton of two tropical reservoirs with different trophic status. Verh. Int. Verein. Limnol., 26: 584-587.

PINTO-COELHO, R. M., CORGOSINHO, P. H. \& SÁ, W. P., 1997b, Variação diurna do status nutricional do zooplâncton em tanques de cultivo de plâncton. Revista Unimar, 19: 521-535.

PINTO-COELHO, R. M., GIANI, A., MORAIS, C., SILVA, E. \& ROCHA, L., 2001, Biomonitoramento plurianual do reservatório da Pampulha. Convênio 3998 SMMA-PBH/ FUNDEP-UFMG, Belo Horizonte, MG, Brasil. Research Grant, Final Report. 89p.

PINTO-COELHO, R. M., BEZERRA-NETO, J. F., GIANI, A., MACEDO, C. F., FIGUEREDO, C. C. \& CARVALHO, E. A., 2003, The collapse of a Daphnia laevis (Birge, 1878) population in Pampulha reservoir, Brazil. Acta Limnol. Brasil, 15: $53-70$.

PORTER, K. G. \& ORCUTT, J. D., 1980, Nutritional adequacy manageability and toxicity as factors that determine the food quality of green and blue green algae for Daphnia. In: W. C. Kerfoot (ed.), Evolution and ecology of zooplankton communities. The University Press, 486p.

REINIKAINEN, M., KETOLA, M., JANTUNEN, M. \& WALLS, M., 1995, Effects of Microcystis aeruginosa exposure and nutritional status on the reproduction of Daphnia pulex. J. Plankton Res., 17: 431-436.

ROOT, E., 1981, Some results from phytoplankton counting intercalibrations. Schweiz. Z. Hydrobiol., 43: 35-62.

SANTEIRO, R. M. \& PINTO-COELHO, R. M., 2000, Efeitos de fertilização na biomassa e qualidade nutricional do zooplâncton utilizado para a alimentação de alevinos na estação de hidrobiologia e piscicultura de Furnas, MG. Acta Scientiarum, 22: 707-716.

SCHINDLER, D. W., 1977, Evolution of phosphorus limitation in lakes. Science, 195: 260-262.

STARLING, F. L. R. \& ROCHA, A. J. A., 1990, Experimental study of the impacts of planktivorous fisher on plankton community and eutrophication of a tropical Brazilian reservoir. Hydrobiologia, 200/201: 581-591.

STERNER, R., ELSER, J. J. \& HESSEN, D. O., 1992, Stoichiometric relationships among producers, consumers and nutrient cycling in pelagic ecosystems. Biogeochemistry, 17: 49-67.

TANG, K. W. \& DAM, H. G., 1996, Limitation of zooplankton production: beyond stoichiometry. Oikos, 84: 537-542.

TORRES, I. C., ARAÚJO, M. A. R. \& PINTO-COELHO, R. M., 1998, Variação temporal de carbono pigmentado, carbono orgânico dissolvido e particulado na Represa da Pampulha, Belo Horizonte/MG. Rev. Brasil. Biol., 58: 131-141.

UTERMÖHL, H., 1958, Perfeccionamento del método cuantitativo del fitoplancton. Commun. Assoc. Int. Limnol. Theor. Appl., 9: 1-89.

VANDERPLOEG, H. A., GARDNER, W. A., PARRISH, C. C., LIEBIG, J. R. \& CAVALETTO, J. F., 1992, Lipids and life cycle of a hypolimnetic copepod in lake Michigan. Limnol. Oceanogr., 37: 413-424

ZOLLNER, N. \& KIRSCH, K., 1962, Ueber die quantitative Bestimmung von Lipoiden (Mikromethode) mittels de vielen natuerlichen Lipoiden (allen bekannten plasmalipoiden) gemeinsamen sulfophosphovnilin-reaktion. Zeit. fuer Ges. Exp. Med., 135: 545-561. 